\title{
Sunflower protein concentrate and crambe protein concentrate in diets for silver catfish Rhamdia quelen (Quoy and Gaimard, 1824): use as sustainable ingredients
}

\author{
NAGLEZI M. LOVATTO ${ }^{1}$, BRUNO B. LOUREIRO ${ }^{1}$, DIRLEISE PIANESSO ${ }^{1}$, \\ TAIDA J. ADORIAN ${ }^{1}$, FERNANDA R. GOULART ${ }^{1}$, CAROLINE S. SPERONI ${ }^{2}$, ANA \\ BETINE B. BENDER ${ }^{2}$, JUCIELI MÜLLER ${ }^{1}$ and LEILA P. DA SILVA ${ }^{1}$ \\ ${ }^{1}$ Departamento de Zootecnia, Centro de Ciências Rurais, Universidade Federal de \\ Santa Maria, Av. Roraima, 1000, 97105-900 Santa Maria, RS, Brazil \\ ${ }^{2}$ Departamento de Tecnologia e Ciência dos Alimentos, Centro de Ciências Rurais, Universidade \\ Federal de Santa Maria, Av. Roraima, 1000, 97105-900 Santa Maria, RS, Brazil
}

Manuscript received on December 7, 2017; accepted for publication on June 18, 2018

\begin{abstract}
The objective of this study was to evaluate growth and metabolic parameters of silver catfish fed with protein concentrates of sunflower meal (SMPC) and crambe meal (CrMPC). The study evaluated two levels of substitution, where 25 or $50 \%$ of animal protein was replaced with plant-based protein. A total of 300 silver catfish $(14 \pm 0.26 \mathrm{~g})$ were used in five treatments and three replications, in fifteen 280-liter experimental units. The results were submitted to analysis of variance and the means of the control diet was compared to the remaining treatments by Dunnett's test at $5 \%$ significance level. At the end of the trial, no differences were observed for the variables final weight and daily weight gain. However, minor feed conversion was observed in the groups Control and SMPC-25\%. Metabolic parameters were analyzed in the plasma and liver, where no significant differences were found for any of the blood parameters analyzed. In the analyzed liver parameters (ammonia, protein, amino acids and ALAT), the liver protein content was lower in fish consuming SMPC-50\%, CrMPC-50\% and 25\% CrMPC diets. The amino acids content was higher in fish receiving the SMPC-25\% diet. It can be concluded that sunflower meal protein concentrate is better utilized by fish and more efficient metabolically than crambe meal. This study demonstrated that a newly developed protein concentrate SMPC and CrMPC can effectively replace $25 \%$ and $50 \%$ the animal protein in a diet free of FM.
\end{abstract}

Key words: Crambe abyssinica, fish feeding, Helianthus annus, jundiá, liver metabolism, plant-based protein concentrates.

\section{INTRODUCTION}

Fish diet formulation aims to obtain highly digestible, nutritionally balanced, economically viable and low environmental impact products

Correspondence to: Naglezi de Menezes Lovatto

E-mail: naglezilovatto@hotmail.com
(Shiau 2002). This concern is mainly related to protein sources, which is the main ingredient in fish nutrition (Cabral et al. 2011). Normally, the main protein source used in fish nutrition is of animal origin, such as fish meal (Santigosa et al. 2011), due to its high nutritional value and balance in essential amino acids (Gatlin et al. 2007, Larsen et al. 2012). 
However, increasing demand, high price and supply fluctuations, makes it a priority to find an alternative replacement to animal protein sources (Larsen et al. 2012). Soybean meal (SBM) is by far the most widely used vegetable protein source in fish diets, followed by sources from other oleaginous plants such as sunflower meal and crambe meal. Leguminous seeds are also good dietary protein sources, particularly if they are locally produced, contributing to the sustainability and cost-effectiveness of fish-farming (Gatlin et al. 2007, Kaushik and Hemre 2010).

The use of plant-based protein sources in fish feeds has expanded considerably in recent years to meet the demand for feeds and sustain the development of worldwide aquaculture production (Tacon and Metian 2015). This protein sources in aquaculture is still challenging, since information on the bioavailability of nutrients are controversial (Cabral et al. 2011) and restraints. The low palatability (Gatlin et al. 2007), imbalance in the amino acid profile (Santigosa et al. 2008) and intrinsic antinutritional factors (Gatlin et al. 2007, Mérida et al. 2010) often restrict its use.

Many studies have focused on the use of plantbased protein sources as sustainable replacements of animal protein sources in fish diets (Gatlin et al. 2007, Tacon and Metian 2008, Hardy 2010, Cabral et al. 2011, Lovatto et al. 2015). Among the potential protein sources, sunflower meal (Helianthus annuus) and crambe meal (Crambe abyssinica) are mentioned. Studies using sunflower meal in fish feed, in different proportions, showed that substitution levels are around $15 \%$ for different species (Olvera-Novoa et al. 2002, Lozano et al. 2007, Mérida et al. 2010) low content lysine and methionine, high fiber content and the presence of antinutritional factors being the limiting aspects. Studies on crambe meal are scarce and there are no definite guidelines for its use in fish feed. The main limiting factors are its high levels of erucic acid, the presence of glucosinolates (Fundação MS 2010) and antinutritional factors for fish.

The use of plant-based protein concentrates is promising as an alternative to the use of in-natura plant-based (Deng et al. 2006). Concentrates enable the obtainment of protein sources with low fiber content (Salze et al. 2010, Larsen et al. 2012), which are free of antinutritional factors and have a better amino acid profile, favoring the digestion (Salze et al. 2010).

The increase in omnivorous fish production is a trend, because they are better adapted to plantbased ingredients (Naylor et al. 2009). Silver catfish (Rhamdia quelen) is an omnivorous fish species, native to southern Brazil (Baldisserotto 2004), which accepts artificial diets with plantbased protein sources. Out of the possible protein sources, soybean meal is the one most commonly used (Coldebella and Radünz Neto 2002, Refstie et al. 2010). However, further studies should focus on the use of different plant-based protein sources, which are underutilized and considered by-products.

This study aims to evaluate the growth and metabolic parameters of silver catfish fed diets containing sunflower meal and crambe meal protein concentrates as substitutes for different levels (25 or $50 \%$ ) of animal protein.

\section{MATERIALS AND METHODS}

\section{OBTAINING THE PLANT-BASED PROTEIN CONCENTRATES AND INGREDIENTS}

Pelleted sunflower meal with hulls (Giovelli Ltda, from Cerro Largo, RS) was milled and later sifted in a granulometer, with $600 \mu \mathrm{m}$ mesh sieves, to remove excess fibers. The crambe cake (FMS Brilhante variety - MS Foundation for Agricultural Technology Research, Maracaju/MS) was defatted with hexane $(2: 1 \mathrm{v} / \mathrm{w})$ to obtain the crambe meal, which was, in turn, used to obtain the protein concentrate. Protein concentrates from sunflower 
and crambe meal were obtained in our laboratory using the methodology described by Smith et al. (1946), with modifications purpose of Lovatto et al. (2017).

Protein enrichment methods with the following changes: 1) The protein was dispersed in an aqueous medium by processing it three times in a blender (LIQ789, Cadence, Brazil) at maximum speed for 3 minutes at room temperature; the meal was blended in water at a ratio of 1:10 - each time. 2) The ground sample was sieved a $140 \mu \mathrm{m}$, and the remaining solid fraction (i.e., the fraction retained in the sieve) was discarded. The liquid fraction was then used for protein extraction. 3) Protein solubilization by isoelectric $\mathrm{pH}$ was carried out by increasing the $\mathrm{pH}$ of the liquid sample to 9.0 with $1 \mathrm{~N} \mathrm{NaOH}$. To precipitate the protein, the $\mathrm{pH}$ of the liquid was then reduced to 4.5 with $1 \mathrm{~N} \mathrm{HCl}$. The solution was conditioned under refrigeration $\left(8^{\circ} \mathrm{C}\right)$ over night to promote decantation of the dispersed protein fraction, followed by discarding the supernatant and drying the concentrated protein fraction in an air recirculation oven at $50^{\circ} \mathrm{C}$ for approximately 24 hours (Lovatto et al. 2017).

The soybean protein concentrate (IMCOSOY $62^{\circledR}$ ) was acquired of IMCOPA, Paraná, Brazil. The pork meat meal was acquired in Fasa Group, Cruzeiro do Sul, Rio Grande do Sul, Brazil. In southern Brazil, pork meat meal is a widely used product and used as a source of animal protein due to the large production of pigs, easily found in local trade, when compared to fish meal (FM).

\section{EXPERIMENTAL DIETS}

Four experimental diets and a control diet (Table I) were used. Two levels (25 and 50\%) of partial substitution of animal protein, replaced by plant-based protein concentrates of sunflower meal (SMPC) and crambe meal (CrMPC) were evaluated. Five isoproteic and isoenergetic diets were formulated to the requirements of $37 \%$ crude protein, in accordance with Meyer and Fracalossi (2004) with $3.200 \mathrm{kcal} \mathrm{ME} \mathrm{kg}^{-1}$ (Jobling 1983) and amino acids in accordance with Montes Girao and Fracalossi (2006). Pork meat meal (Fasa, Brazil) and soy protein concentrate (Imcosoy $62^{\circledR}$, Brazil) were used as protein base in the diet control. The chemical composition and amino acid profile are described in Table I.

For diets preparation, the ingredients were weighed and mixed until complete homogenization of the diets. Subsequently water was added and the pellets of the high density and size of $4 \mathrm{~mm}$ were pelletized and later dried in an oven with forced air circulation at $50^{\circ} \mathrm{C}$ for 24 hours.

\section{GROWTH TRIAL AND SAMPLING}

This study was carried out at the experimental fish farm and laboratory of the Federal University of Santa Maria (Universidade Federal de Santa Maria- UFSM) in southern Brazil. All procedures involving animals were carried out in compliance with the guidelines approved by the Committee on Research Ethics and Animal Welfare of said university, protocol number 23081.004071/201195. The fish were acquired from Fish Culture Station of the University of Passo Fundo, Rio Grande do Sul, Brazil.

A total of 300 silver catfish, with initial mean weight of $14 \pm 0.26 \mathrm{~g}$, were distributed into fifteen 280-litter polypropylene tanks (corresponding to 20 animals per tank), with individual water inlets and outlets, connected to a water recirculating system consisting of two biological filters with gravel, backwash system and controlled temperature. The fish were acclimated for a two week period, were fed to control feed and for seven weeks the fish were fed the experimental diets.

In the early and late experimental period (seven weeks of treatment), biometrics was performed to collect data. Animals fasted for $24 \mathrm{~h}$, were anesthetized using Eugenol $20 \mathrm{mg} . \mathrm{L}^{-1}$ in the water 
TABLE I

Formulation, chemical composition and calculated amino acids of the experimental diets containing protein concentrate of sunflower meal and crambe meal in different proportions in diet $\left(\mathrm{g} \mathrm{kg}^{-1}\right)$.

\begin{tabular}{|c|c|c|c|c|c|}
\hline \multirow{2}{*}{ Ingredients ( $\left.\mathrm{g} \mathrm{kg}^{-1}\right)$} & \multicolumn{5}{|c|}{ 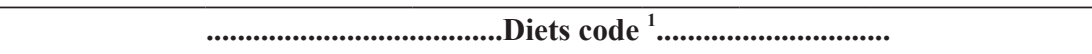 } \\
\hline & CONTROL & SMPC-50\% & CrMPC- $50 \%$ & SMPC-25\% & CrMPC-25\% \\
\hline \multicolumn{6}{|c|}{ Diet formulation $\left(\mathrm{g} \mathrm{kg}^{-1}\right)$} \\
\hline Corn & 195 & 177.7 & 200 & 230 & 220 \\
\hline Corn starch & 24 & 67 & 15 & 30 & 16.5 \\
\hline $\mathrm{DRM}^{2}$ & 37 & 30 & 45 & 60 & 65 \\
\hline IMCOSOY $62^{\circledR 3}$ & 260 & 260.9 & 257.7 & 250 & 250 \\
\hline $\mathrm{SMPC}^{* 4}$ & - & 176 & - & 88 & - \\
\hline $\mathrm{CrMPC}^{* 5}$ & - & - & 179.3 & - & 89.7 \\
\hline $\mathrm{PMM}^{6}$ & 300 & 149.9 & 149.9 & 224.9 & 224.9 \\
\hline Soy oil & 35 & 106.4 & 45 & 65 & 35 \\
\hline Vitamins and minerals $^{7}$ & 30 & 30 & 30 & 30 & 30 \\
\hline Dicalcium phosphate & 36.4 & - & 4 & - & 2.5 \\
\hline $\mathrm{MSG}^{8}$ & 2.5 & 2 & 2.5 & 2 & 2.5 \\
\hline $\mathrm{BHT}^{9}$ & 0.1 & 0.1 & 0.1 & 0.1 & 0.1 \\
\hline Limestone & 22 & - & 18 & 15 & 20 \\
\hline Inert $^{10}$ & 58 & - & 53.5 & 5 & 43.8 \\
\hline L-lysine & - & - & 0.8 & - & - \\
\hline DL-methionine & 3.2 & 2.5 & 2.3 & 1.7 & 5.1 \\
\hline \multicolumn{6}{|c|}{ Diets chemical composition $\left(\mathrm{g} \mathrm{kg}^{-1}\right)$} \\
\hline Dry matter & 955.5 & 970.6 & 961.6 & 948.8 & 948.2 \\
\hline Crude protein* & 370.7 & 368.5 & 371.1 & 371.4 & 371.5 \\
\hline Mineral matter & 42.8 & 34.9 & 46.5 & 45.0 & 47.8 \\
\hline Calcium & 37.8 & 11.0 & 18.6 & 21.4 & 23.9 \\
\hline Phosphorus & 19.9 & 8.2 & 9.7 & 11.5 & 12.2 \\
\hline $\mathrm{NDF}^{11}$ & 62.8 & 94.8 & 102.2 & 86.8 & 88.6 \\
\hline Lipids & 103.2 & 154.5 & 105.3 & 124.9 & 100.3 \\
\hline Digestible energy $^{12}\left(\mathrm{MJ} \mathrm{kg}^{-1}\right)$ & 13.41 & 13.40 & 13.40 & 13.41 & 13.40 \\
\hline \multirow{2}{*}{\multicolumn{6}{|c|}{ Calculated amino acids ${ }^{14}\left(\mathrm{~g} \mathrm{~kg}^{-1} \text { of the diets }\right)^{320.7}$}} \\
\hline & & & & & \\
\hline Lysine & 20.4 & 18.9 & $\begin{array}{ll}16.7 \\
\end{array}$ & 20.4 & 20.4 \\
\hline Methionine + cystine & 13.7 & 13.7 & 13.7 & 13.7 & 13.7 \\
\hline Threonine & 12.8 & 10.2 & 10.2 & 13.0 & 13.8 \\
\hline Tryptophan & 1.3 & 0.7 & 0.7 & 1.8 & 1.0 \\
\hline Valine & 16.3 & 12.8 & 13.0 & 16.9 & 17.3 \\
\hline Isoleucine & 12.7 & 10.2 & 10.3 & 14.6 & 11.4 \\
\hline Leucine & 23.7 & 18.8 & 19.0 & 26.5 & 24.5 \\
\hline Phenylalanine+tyrosine & 14.8 & 12.3 & 12.4 & 17.7 & 15.7 \\
\hline Histidine & 9.2 & 7.4 & 7.5 & 11.1 & 9.7 \\
\hline Arginine & 21.9 & 16.4 & 16.6 & 27.2 & 21.8 \\
\hline
\end{tabular}

*Crude protein of protein concentrates: $51.36 \%$ (sunflower) and 50.42\% (crambe);

${ }^{1}$ Diets: SMPC-50\% and SMPC-25\%: sunflower meal protein concentrate, replacing 50\% or $25 \%$ of the pork meat and bone meal; CrMPC-50\% and CrMPC- $25 \%$ : crambe meal protein concentrate, replacing $50 \%$ or $25 \%$ of the protein meat and bone meal swine;

${ }^{2}$ Defatted rice mean;

${ }^{3}$ Soy protein concentrate $60 \%\left(\right.$ CPS $\left.60^{\circledR}\right)$, Imcopa, Brazil;

${ }^{4}$ Sunflower meal protein concentrate;

${ }^{5}$ Crambe meal protein concentrate;

${ }^{6}$ Pork meat and bone meal;

${ }^{7}$ Vitamins and minerals (kg/product): folic acid: $299.88 \mathrm{mg}$, ascorbic acid: $15000.12 \mathrm{mg}$, pantothenic acid: $3000.10 \mathrm{mg}$, biotin: $0.06 \mathrm{mg}$, vitamin B3: $9000.32 \mathrm{mg}$, vitamin B4: $103.500 \mathrm{mg}$, vitamin A: 1000.000 UI, vitamin B1: $1500.38 \mathrm{mg}$, vitamin B2: $1500.00 \mathrm{mg}$, vitamin B6: $1500.38 \mathrm{mg}$, vitamin D3: 240000.00 UI, vitamin E: $10000.00 \mathrm{mg}$, vitamin K3: $400.00 \mathrm{mg}$, vitamin B8: $9999.92 \mathrm{mg}$, iron: $6416.80 \mathrm{mg}$, manganese: $8000.40 \mathrm{mg}$, copper: $1000.00 \mathrm{mg}$, zinc: $13999.50 \mathrm{mg}$, iodine: $45.36 \mathrm{mg}$, cobalt: $60.06 \mathrm{mg}$, selenium: $60.30 \mathrm{mg}$, magnesium: $5.10 \mathrm{mg}$, chlorine: $23000.00 \mathrm{mg}$, sulfur: $100 \mathrm{mg}$;

${ }^{8}$ Glutamate monosodium;

${ }^{9}$ Butyl-hydroxy-toluene (antioxidant);

${ }^{10}$ Sand;

${ }^{11}$ Neutral detergent fiber (Van Soest et al. 1991);

${ }^{12}$ Digestible energy calculated according to Jobling $(1983)=[($ crude protein $* 23.61 \mathrm{MJ} / \mathrm{kg} * 0.9)+($ Fat $* 39.82 \mathrm{MJ} / \mathrm{kg} * 0.85)+(\mathrm{Neutral}$ detergent soluble Carbohydrate * $17.21 \mathrm{MJ} / \mathrm{kg} * 0.50)$;

${ }^{13}$ Soluble detergent carbohydrates $=100-($ Moisture + Crude protein + Mineal matter + Ethereal extract + Neutral detergent fiber $)$;

${ }^{14}$ Amino acids analyzed the ingredients (Laboratory of Analysis Mycotoxicologic (LAMIC - CCR / UFSM, Brazil) and calculated in the diets. 
(Cunha et al. 2010) and slaughtered by cervical puncture. The following data were collected: Final weight (g): final weight obtained at the end of the period; AFC: Apparent feed conversion $=[($ Total feed intake)/(final biomass - initial biomass)]; DWG: daily weight gain $(\mathrm{g})=[$ (final weight initial weight $) /$ day $]$; survival $(\%)=[($ Total number of fish harvested/total number of fish stocked) $\mathrm{x}$ $100]$ and hepatosomatic index (HSI) (\%): [(weight of the liver/weight of the whole fish) $\mathrm{x} 100]$.

\section{WATER QUALITY RECIRCULATION SYSTEM}

During the experimental period, the physical/ chemical variables of water quality were measured. During the trial, temperature was kept at $24.9 \pm$ $1.5^{\circ} \mathrm{C}$, oxygen concentration $6.7 \pm 0.4 \mathrm{mg} \mathrm{L}^{-1}$, total ammonia $0.15 \pm 0.06 \mathrm{mg} \mathrm{L}^{-1}$, nitrite $0.16 \pm 0.1 \mathrm{mg}$ $\mathrm{L}^{-1}, \mathrm{pH} 7.3 \pm 0.2$, Alkalinity $48.8 \pm 13.7 \mathrm{mg} \mathrm{CaCO}_{3}$ $\mathrm{L}^{-1}$ and hardness of $56.4 \pm 34.6 \mathrm{mg} \mathrm{CaCO}_{3} \mathrm{~L}^{-1}$. The levels of water quality remained ideal for temperate climate fish (Baldisserotto 2004).

\section{PLASMA BIOCHEMISTRY AND HEPATIC} METABOLISM ASSAY

In the late experimental period, after fasting for $24 \mathrm{~h}$, nine fish were captured per treatment. Blood was quickly collected from the caudal vein using heparinized syringes and the fish slaughtered by spinal cord excision behind the operculum and eviscerated to remove the liver. Thereafter, livers were quickly placed on ice and frozen at $-20^{\circ} \mathrm{C}$ for biochemical parameters analysis. Plasma aliquots were separated after blood centrifugation at room temperature for $10 \mathrm{~min}$ at $1200 \times \mathrm{g}$ for posterior determination of plasmatic metabolic parameters: glucose, total proteins, triglycerides, cholesterol and albumin, using commercial kits (Doles ${ }^{\circledR}$ Reagents and Laboratory Equipment Ltda. Goiania, Goiás, Brazil).

Liver glycogen levels were determined according to Bidinotto et al. (1997). The liver tissue was weighed (50 mg), and $\mathrm{KOH}$ and ethanol (1 and
$3 \mathrm{~mL}$, respectively) were added for hydrolysis and glycogen precipitation. For hepatic protein analysis, the tissues were heated at $100^{\circ} \mathrm{C}$ with $\mathrm{KOH}$ and centrifuged at $1000 \times \mathrm{g}$ for $10 \mathrm{~min}$. Supernatant was used to estimate the total protein level according to the method described by Bradford (1976), using bovine albumin serum as standard.

To measure hepatic amino acids, ammonia and transaminases, liver samples were mechanically disrupted by adding trichloroacetic acid $10 \%$ and the homogenate was centrifuged at $1000 \times \mathrm{g}$ for 10 min. The neutral supernatant extract was used for amino acid colorimetric determination according to Spies (1957), using ninhydrin $1.5 \%$ in isopropyl alcohol as the color reagent. Hepatic ammonia was measured by colorimetry according to Verdouw et al. (1978).

This neutral extract was used to measure the hepatic transaminases concentration, but it was necessary to dilute the crude extract in homogenization buffer for the protein and alanine aminotransferase (ALAT) (EC 2.6.1.2). The enzymes were determined using colorimetric procedures following the protocols described in the kits $\left(\right.$ Doles $\left.^{\circledR}\right)$. ALAT concentration was expressed as UI. $\mathrm{mg}^{-1}$ hepatic tissue.

\section{STATISTICAL ANALYSIS}

The experimental design was completely randomized. The results were submitted to analysis of variance (one-way ANOVA). The means of the control diet were compared to the means of the other treatments by the Dunnett's test at the 5\% level of significance, using SPSS 8.0 software.

\section{RESULTS}

GROWTH PARAMETERS, SURVIVAL AND HEPATOSOMATIC INDEX

No differences $(\mathrm{P}>0.05)$ were observed in the final weight and daily weight gain (DWG) (Table II) 
TABLE II

Growth parameters, survival and hepatosomatic index of silver catfish juveniles of different experimental groups fed different experimental diets.

\begin{tabular}{|c|c|c|c|c|c|}
\hline \multirow{2}{*}{ Variables $^{1}$} & \multicolumn{5}{|c|}{ 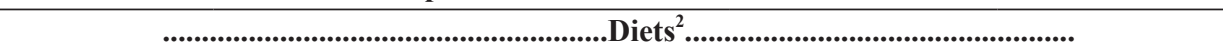 } \\
\hline & CONTROL & SMPC-50\% & CrMPC-50\% & SMPC-25\% & CrMPC-25\% \\
\hline Final weight (g) & $44.72 \pm 3.77$ & $47.10 \pm 3.84$ & $45.48 \pm 7.41$ & $48.24 \pm 0.32$ & $46.98 \pm 7.82$ \\
\hline $\mathrm{AFC}$ & $1.13 \pm 0.12$ & $1.43 \pm 0.21 *$ & $1.57 \pm 0.14^{*}$ & $1.17 \pm 0.08$ & $1.42 \pm 0.05^{*}$ \\
\hline DWG $(\mathrm{g})$ & $0.59 \pm 0.07$ & $0.64 \pm 0.07$ & $0.61 \pm 0.05$ & $0.66 \pm 0.02$ & $0.62 \pm 0.07$ \\
\hline Survival (\%) & 100 & 100 & 100 & 100 & 100 \\
\hline HSI (\%) & $1.43 \pm 0.10$ & $1.64 \pm 0.20$ & $1.56 \pm 0.20$ & $1.50 \pm 0.10$ & $1.46 \pm 0.20$ \\
\hline
\end{tabular}

Values represented as mean \pm standard deviation. The means with $(*)$ differ significantly from the control diet by Dunnett's test $(\mathrm{P}<0.05)$.

${ }^{1} \mathrm{AFC}$ : Apparent feed conversion, $\mathrm{n}-60$;

DWG: daily weight gain, n-60;

HSI: hepatosomatic index, n-9;

${ }^{2}$ Diets: SMPC-50\% and SMPC-25\%: sunflower meal protein concentrate, replacing $50 \%$ or $25 \%$ of the protein pork meat and bone meal; CrMPC-50\% and CrMPC-25\%: crambe meal protein concentrate, replacing $50 \%$ or $25 \%$ of the protein pork meat and bone meal.

of fish fed diets containing 25 or 50\% SMPC and CrMPC when compared to the fish that received the control diet. The best $(\mathrm{P}<0.05)$ feed conversion (FC) was observed in the Control and SMPC-25\% treatments. Lower efficiency in $\mathrm{FC}$ was observed for fish receiving the SMPC-50\%, CrMPC-50\% and CrPC-25\% diets (Table II). No difference ( $\mathrm{P}>0.05$ ) was observed for survival, in all treatments survival was $100 \%$.

The fish submitted to the experimental diets showed no difference $(\mathrm{P}>0.05)$ regarding the hepatosomatic index (HSI) (Table II).

\section{PLASMA BIOCHEMISTRY ASSAY}

Plasmatic levels of glucose, total proteins, albumin, cholesterol and triglycerides (Table III) did not differ $(\mathrm{P}>0.05)$ of fish fed diets containing 25 or $50 \%$ SMPC and CrMPC when compared to the control treatment.

\section{HEPATIC METABOLISM ASSAY}

There was no significant difference $(\mathrm{P}>0.05)$ in hepatic ammonia levels among tested diets (Table IV). Lower content $(\mathrm{P}<0.05)$ of hepatic protein was observed in fish from diets SMPC-50\%,
CrMPC-50\% and CrMPC-25\% when compared to the control diet. The hepatic protein content of the fish fed the SMPC-25\% diet did not differ $(\mathrm{P}>0.05)$ from the control diet (Table IV). There was an increase $(\mathrm{P}<0.05)$ in free amino acids content in the liver of fish fed the SMPC-25\% diet (Table IV). There was no significant difference $(\mathrm{P}>0.05)$ in ALAT hepatic activity for fish fed diets containing the plant-based protein concentrates when compared to the control diet (Table IV).

\section{DISCUSSION}

Diets containing plant-based protein concentrates (SMPC- 25\% and 50\% and CrMPC- 25\% and $50 \%$ ) provided similar growth rates to those observed in the control diet. These results confirm the efficiency of the concentrates as protein sources in the diet of silver catfish ( $R$. quelen). The FC of the fish submitted to the SMPC-25\% treatment may be related to the better protein quality of the diets. Furthermore, the values found for FC are similar to those observed in other studies (Piedras et al. 2004, Freitas et al. 2011). Increased HSI is generally observed for fish fed diets containing high levels of carbohydrates (Debnath et al. 2007) in association 
TABLE III

Plasma biochemistry values for silver catfish of different experimental groups fed different experimental diets.

\begin{tabular}{|c|c|c|c|c|c|}
\hline \multirow{2}{*}{ Plasma levels } & \multicolumn{5}{|c|}{  } \\
\hline & CONTROL & SMPC-50\% & CrMPC-50\% & SMPC-25\% & CrMPC-25\% \\
\hline Glucose $\left(\mathrm{mg} \cdot \mathrm{dL}^{-1}\right)$ & $50.12 \pm 6.40$ & $49.40 \pm 7.90$ & $52.67 \pm 8.00$ & $56.10 \pm 11.50$ & $47.26 \pm 9.60$ \\
\hline Total proteins $\left(\mathrm{g} \cdot \mathrm{L}^{-1}\right)$ & $4.13 \pm 0.60$ & $3.96 \pm 0.30$ & $4.03 \pm 0.70$ & $4.20 \pm 0.50$ & $4.34 \pm 0.40$ \\
\hline Albumin $\left(\mathrm{g} \cdot \mathrm{L}^{-1}\right)$ & $0.82 \pm 0.20$ & $0.79 \pm 0.20$ & $0.74 \pm 0.10$ & $0.86 \pm 0.10$ & $0.67 \pm 0.20$ \\
\hline Cholesterol (mg.dL $\left.{ }^{-1}\right)$ & $130.71 \pm 8.60$ & $152.39 \pm 26.10$ & $122.11 \pm 20.20$ & $139.52 \pm 24.40$ & $119.72 \pm 32.20$ \\
\hline Triglycerides (mg.dL $\left.{ }^{-1}\right)$ & $703.19 \pm 260.80$ & $694.08 \pm 312.30$ & $610.25 \pm 131.00$ & $730.14 \pm 149.60$ & $580.63 \pm 184.40$ \\
\hline
\end{tabular}

Values represented as mean \pm standard deviation, $n-9$.

${ }^{1}$ Diets: SMPC-50\% and SMPC-25\%: sunflower meal protein concentrate, replacing $50 \%$ or $25 \%$ of the protein pork meat and bone meal; CrMPC-50\% and CrMPC-25\%: crambe meal protein concentrate, replacing $50 \%$ or $25 \%$ of the protein pork meat and bone meal.

TABLE IV

Hepatic biochemistry values for silver catfish of different experimental groups fed different experimental diets.

\begin{tabular}{cccccc}
\hline & & ..................................................Diets ${ }^{1}$.................................................... & & \\
& CONTROL & SMPC-50\% & CrMPC-50\% & SMPC-25\% & CrMPC-25\% \\
\hline Glycogen (\%) & $9.56 \pm 4.00$ & $6.18 \pm 2.11^{*}$ & $4.42 \pm 1.47 *$ & $9.82 \pm 1.74$ & $5.41 \pm 2.13 *$ \\
Protein (mg.g ${ }^{-1}$ ) & $0.038 \pm 0.006$ & $0.031 \pm 0.002$ & $0.025 \pm 0.002 *$ & $0.032 \pm 0.008$ & $0.029 \pm 0.001 *$ \\
Ammonia (mM.g $\left.{ }^{-1}\right)$ & $12.09 \pm 5.22$ & $9.84 \pm 2.57$ & $11.02 \pm 2.11$ & $13.089 \pm 3.75$ & $12.89 \pm 5.57$ \\
Amino Acids (mg.g $\left.{ }^{-1}\right)$ & $35.21 \pm 12.31$ & $45.36 \pm 14.00$ & $46.87 \pm 10.45$ & $87.73 \pm 23.29 *$ & $52.96 \pm 14.25$ \\
ALAT (UI.mg ${ }^{-1}$ ) & $7.19 \pm 2.70$ & $3.96 \pm 0.54$ & $4.81 \pm 1.06$ & $4.44 \pm 0.42$ & $5.57 \pm 1.84$ \\
\hline
\end{tabular}

Values represented as mean \pm standard deviation, $n-9$. The means with $(*)$ differ significantly from the control diet by Dunnett's test $(\mathrm{P}<0.05)$.

${ }^{1}$ Diets: SMPC-50\% and SMPC-25\%: sunflower meal protein concentrate, replacing $50 \%$ or $25 \%$ of the protein pork meat and bone meal; CrMPC-50\% and CrMPC-25\%: crambe meal protein concentrate, replacing $50 \%$ or $25 \%$ of the protein pork meat and bone meal.

to the increase in hepatic glycogen content, which was not observed in our study.

Borges et al. (2004) observed blood reference parameters in silver catfish, which were similar to those found in the present study, and no differences were observed among the treatments tested. This demonstrates that plasmatic levels were not altered by the use of plant protein concentrates in the diet of silver catfish juveniles.

The maintenance of normal levels of total circulating proteins is indicative of protein catabolism, which means that the protein in the diet is being used and metabolized, because when blood protein levels are low, liver protein synthesis is impaired (Lieberman et al. 2007). In addition, serum albumin serves as an indicator of dietary protein quality (Lehninger et al. 2004) and the results may suggest that plant-based protein concentrates have provided the necessary protein for fish development.

The fish that received the diets containing CrMPC-25\% and 50\% also had lower levels of hepatic protein, when compared to the fish on the control diet. This fact may have occurred due to the glycogen mobilization in fish being slow and the gluconeogenic pathway by synthesizing glucose through carbon skeletons (Halver and Hardy 2002) being preferred, since the fish fed those same diets (CrMPC-25\% and CrMPC-50\%) also had lower rates of hepatic glycogen. According to Bombardelli 
et al. (2003), in a fasting state fish first mobilize the protein pool and pool of circulating amino acids before mobilizing hepatic glycogen, suggesting that the use of glycogen stock is performed when dietary proteins are not catabolized correctly.

In our study, there was no increase in hepatic ammonia. Lund et al. (2011) have shown that ammonia excretion is high in fish diets containing plant-based protein sources. This trend was not evidenced in our study, thus, it is suggested that the protein concentrates used in the diets presented adequate nutritional value. Larsen et al. (2012) found higher levels of ammonia for Oncorhynchus mykiss using plant-based protein sources, suggesting less efficient use of dietary proteins, unlike our results. Vieira et al. (2005) reported that the increase in free amino acid content in the liver is related to the higher synthesis of dietary protein. In fish, it is known that tissue amino acid levels are affected by both the amount and quality of the dietary protein (Yamamoto et al. 2000). The same authors have found a high correlation between the protein and amino acids contained in the diet, with those contained in the tissues (blood, liver and muscle).

Authors report that fish fed diets containing plant-based protein sources have lower ALAT activity in the liver, indicating that the protein transamination was not suppressed (GómezRequeni et al. 2004, Hansen et al. 2007).

The study of the metabolism within fish liver is crucial to elucidate and understand how well silver catfish diets adapt to different protein sources. Since the use of plant-based protein sources tends to increase linearly in feeding omnivorous fish (Naylor et al. 2009), it is likely that the dietary source will directly affect the endogenous protein/ amino acid metabolism (Larsen et al. 2012).

In our study it was observed that among the protein concentrates obtained from different coproducts, the SMPC was more metabolically efficient and better utilized by the fish than the
CrMPC. The fish that received the SMPC-25\% diet had the best metabolic efficiency of the ingredients. Further studies are needed to confirm the use of these proteins concentrates in the diet of silver catfish. From the production of protein concentrates on an industrial scale, up to carrying out a study with a longer experimental period, aiming at growth and fattening of the fish.

Is essential for the future development of global feed aquaculture that continued to develop new obtention feed products that are ethical, economical and sustainable. The FM based feeds become more expensive, due to increases, and then the protein demand will need to be met using largely plant-based alternatives and processing byproducts from other industries (Bell et al. 2016).

This study demonstrated that a newly developed protein concentrate SMPC and CrMPC can effectively replace $25 \%$ and $50 \%$ the animal protein in a diet free of FM. However, the results indicate that SMPC was more metabolically efficient and better utilized by the fish than CrMPC. Furthermore, data demonstrate that it is possible to use only $15 \%$ of animal protein, in diets whit SMPC for silver catfish, without prejudice to the growth and hepatic metabolism of fish.

\section{ACKNOWLEDGMENTS}

The authors would like to thank the Ministério da Ciência e Tecnologia (MCT) / Conselho Nacional de Desenvolvimento Científico e Tecnológico (CNPq), the Fundo Setorial do Agronegócio (CTAGRO - MCT/CNPq), the Ministério da Pesca e Aquicultura (MPA), and CNPq for the Master's scholarship awarded.

\section{REFERENCES}

BALDISSEROTTO B. 2004. Biologia do Jundiá. In: Baldisserotto B and Radünz Neto J (Eds), Criação de jundiá, Santa Maria: Editora UFSM, p. 67-72.

BELL JG, STRACHAN F, ROY WJ, MATTHEW C, MCDONALD P, BARROWS FT AND SPRAGUE M. 
2016. Evaluation of barley protein concentrate and fish protein concentrate, made from trimmings, as sustainable ingredients in Atlantic salmon (Salmo salar L.) feeds. Aquacult Nutr 22: 326-334.

BIDINOTTO PM, SOUZA RHS AND MORAES G. 1997. Hepatic glycogen in eight tropical freshwater teleost fish: Procedure for field determinations of microsamples. B Técnico do CEPTA 10: 53-60.

BOMBARDELLI RA, MEURER F AND SYPERRECK MA. 2003. Metabolismo proteico em peixes. Arq Ciênc Vet Zool 7: 69-79.

BORGES A, SCOTTI LV, SIQUEIRA DR, JURINITZ DF AND WASSERMANN GF. 2004. Hematologic and serum biochemical values for jundiá (Rhamdia quelen). Fish Physiol Biochem 30(1): 21-25.

BRADFORD MMA. 1976. A rapid and sensitive method for the quantification of microgram quantities of protein utilizing the principle of protein-dye binding. Anal Biochem 72: 248-254.

CABRAL EM, BACELAR M, BATISTA S, CASTROCUNHA M, OZÓRIO ROA AND VALENTE LMP. 2011. Replacement of fish meal by increasing levels of plant protein blends in diets for Senegalese sole (Solea senegalensis) juveniles. Aquaculture 322-323: 74-81.

COLDEBELLA IJ AND RADÜNZ NETO J. 2002. Farelo de soja na alimentação de alevinos de jundiá (Rhamdia quelen). Cienc Rural 32: 499-503.

CUNHA MA, ZEPPENFELD CC, GARCIA LO, LORO VL, FONSECA MB, EMANUELLI T, VEECK APL, COPATTI CE AND BALDISSEROTTO B. 2010. Anesthesia of silver catfish with eugenol: time of induction, cortisol response and sensory analyses of fillet. Cienc Rural 40: 2107-2114.

DEBNATH D, PAL AK, SAHU NP, YENGKOKPAM $\mathrm{S}$, BARUAH K, CHOUDHURY D AND VENKATESHWARLU G. 2007. Digestive enzymes and metabolic profile of Labeo rohita fingerlings fed diets with different crude protein levels. Comp Biochem Physiol Part B 146: 107-114.

DENG J, MAI K, AI A, ZHANG W, WANG H, XU W AND LIUFU Z. 2006. Effects of replacing fish meal with soy protein concentrate on feed intake and growth of juvenile Japanese flounder, Paralichthys olivaceus. Aquaculture 258: 503-513.

FREITAS JMA, SARY C, LUCHESI JD, FEIDEN A AND BOSCOLO WR. 2011. Proteína e energia na dieta de jundiás criados em tanques-rede. R Bras Zootec 40: 26282633.

FUNDAÇÃO MS. 2010. Tecnologia e Produção: Crambe 2010. Maracaju: Fundação MS, 60 p.

GATLIN DM ET AL. 2007. Expanding the utilization of sustainable plant products in aquafeeds: a review. Aquacult Res 38: 551-579.
GÓMEZ-REQUENI P, MINGARRO M, CALDUCH-GINER JA, MÉDALE F, MARTIN SAM, HOULIHAN DF, KAUSHIK S AND PÉREZ-SÁNCHEZ J. 2004. Protein growth performance, amino acid utilisation and somatotropic axis responsiveness to fish meal replacement by plant protein sources in gilthead sea bream (Sparus aurata). Aquaculture 232: 493-510.

HALVER JE AND HARDY RW. 2002. Nutrient Flow and Retention. In: Halver JE (Ed), Fish nutrition, 3rd revised, New York: Academic Press, p. 755-770.

HANSEN AC, ROSENLUND G, KARLSEN Ø, KOPPE W AND HEMRE GI. 2007. Total replacement of fish meal with plant proteins in diets for Atlantic cod (Gadus morhua L.) I - Effects on growth and protein retention. Aquaculture 272: 599-611.

HARDY RW. 2010. Utilization of plant proteins in fish diets: effects of global demand and supplies of fishmeal. Aquacult Res 41: 770-776.

JOBLING M. 1983. A short review and critic of methodology used in fish growth and nutrition studies. J Fish Biol 23: 685-703.

KAUSHIK S AND HEMRE GI. 2010. Plant proteins as alternative sources for fish feed and farmed fish quality. In: Lie $\varnothing$ (Ed), Improving farmed fish quality and safety, Cambridge: CRC Press, p. 300-319.

LARSEN BK, DALSGAARD J AND PEDERSEN PB. 2012. Effects of plant proteins on post prandial, free plasma amino acid concentrations in rainbow trout (Oncorhynchus mykiss). Aquaculture 326-329: 90-98.

LEHNINGER AL, NELSON DL AND COX MM. 2004. Principles of Biochemistry: 4th ed., New York: WH Freeman, $1119 \mathrm{p}$.

LOVATTO NM, GOULART FR, FREITAS ST, MOMBACH PI, BENDER ABB, BOLIGON AA, RADÜNZ NETO J AND SILVA LP. 2015. Nutritional evaluation of phosphorylated pumpkin seed (Cucurbita moschata) protein concentrate in silver catfish Rhamdia quelen (Quoy and Gaimard, 1824). Fish Physiol Biochem 41(6): 1557-1567.

LOVATTO NM, GOULART NM, LOUREIRO NM, SPERONI, CS, BENDER ABB, GIACOMINI SJ, RADÜNZ NETO J AND SILVA LP. 2017. Crambe (Crambe abyssinica) and sunflower (Helianthus annuus) protein concentrates: production methods and nutritional properties for use in fish feed. An Acad Bras Cienc 89(3 Suppl.): 2495-2504.

LIEBERMAN M, MARKS AD AND SMITH C. 2007. Marks' Basic Medical Biochemistry: A Clinical Approach, 2nd ed., Lippincott Williams \& Wilkins, 920 p.

LOZANO NBS, VIDAL AT, MARTINÉZ-LLORENS S, MÉRIDA SN, BLANCO JE, LÓPEZ AM, TORRES MA AND CERDÁ MJ. 2007. Growth and economic profit of 
gilthead sea bream (Sparus aurata L.) fed sunflower meal. Aquaculture 272: 528-534.

LUND I, DALSGAARD J, RASMUSSEN HT, HOLM J AND JOKUMSEN A. 2011. Replacement of fish meal with a matrix of organic plant proteins in organic trout (Oncorhynchus mykiss) feed. Aquaculture 321: 259-266.

MÉRIDA SN, VIDAL AT, LLORENS SM AND CERDÁ MJ. 2010. Sunflower meal as a partial substitute in juvenile sharpsnout sea bream (Diplodus puntazzo) diets: Amino acid retention, gut and liver histology. Aquaculture 298: 275-281.

MEYER G AND FRACALOSSI DM. 2004. Protein requirement of jundia fingerlings, Rhamdia quelen, at two dietary energy concentrations. Aquaculture 240: 331-343.

MONTES-GIRAO PJ AND FRACALOSSI DM. 2006. Dietary lysine requirement as basis to estimate the essential dietary amino acid profile for jundiá, Rhamdia quelen. J World Aquacult Soc 37: 388-396.

NAYLOR RL ET AL. 2009. Feeding aquaculture in an era of infinite resources. Proc Natl Acad Sci USA 106: 1510315110.

OLVERA-NOVOA MA, OLIVERA-CASTILLO LE AND MÁRTINEZ-PALACIOS CA. 2002. Sunflower seed meal as a protein source in diets for Tilapia rendalli (Boulanger, 1896) fingerlings. Aquacult Res 33: 223-229.

PIEDRAS SRN, MORAES PRR AND POUEY JLOF. 2004. Crescimento de juvenis de jundiá (Rhamdia quelen), de acordo com a temperatura da água. Instit de Pesca 30: 177182.

REFSTIE S, BAEVERFJORD G, SEIM RR AND ELVEBØ O. 2010. Effects of dietary yeast cell wall $\beta$-glucans and MOS on performance, gut health, and salmon lice resistance in Atlantic salmon (Salmo salar) fed sunflower and soybean meal. Aquaculture 305: 109-116.

SALZE G, MCLEAN E, BATTLE PR, SCHWARZ MH AND CRAIG SR. 2010. Use of soy protein concentrate and novel ingredients in the total elimination of fish meal and fish oil in diets for juvenile cobia, Rachycentron canadum. Aquaculture 298: 294-299.

SANTIGOSA E, GARCÍA-MEILÁN I, VALENTIN JM, PÉREZ-SÁNCHEZ J, MÉDALE F, KAUSHIK S AND GALLARDO MA. 2011. Modifications of intestinal nutrient absorption in response to dietary fish meal replacement by plant protein sources in sea bream (Sparus aurata) and rainbow trout (Onchorynchus mykiss). Aquaculture 317: 146-154.

SANTIGOSA E, SANCHÉS J, MÉDALE F, KAUSHIK S, PÉREZ-SÁNCHEZ J AND GALLARDO MA. 2008. Modifications of digestive enzymes in trout (Oncorhynchus mykiss) and sea bream (Sparus aurata) in response to dietary fish meal replacement by plant protein sources. Aquaculture 282: 68-74.

SHIAU SY. 2002. Tilapia, Oreochromis spp. In: Webster CD and Lim C (Eds), Nutrient Requirement and Feeding of Finfish for Aquaculture. London: CABI Publishing, p. 273-292.

SMITH AK, JOHNSON VL AND BECKEL AC. 1946. Linseed proteins alkali dispersion and acid precipitation. $\mathrm{J}$ Ind Eng Chem 38: 353-356.

SPIES JR. 1957. Colorimetric procedures for amino acids. Methods in Enzymology 3: 467-477.

TACON AGJ AND METIAN M. 2008. Global overview on the use of fish meal and fish oil in industrially compounded aquafeeds: trends and future prospects. Aquaculture 285: 146-158.

TACON AGJ AND METIAN M. 2015. Feed Matters: Satisfying the Feed Demand of Aquaculture. Rev Fish Sci 23(1): 1-10.

VAN SOEST PJ, ROBERTSON JB AND LEWIS BA. 1991. Methods for dietary fiber, neutral detergent fiber, and nonstarch polysaccharides in relation to animal nutrition. J Dairy Sci 74: 3583-3597.

VERDOUW H, VANECHTELD CJA AND DECKKERS EMJ. 1978. Ammonia determinations based on indophenol formation with sodium salicylate. Water Res 12: 399-402.

VIEIRA VP, INOUEB LAK AND MORAES G. 2005. Metabolic responses of matrinxã (Brycon cephalus) to dietary protein level. Comp Biochem Physiol A Mol Integr Physiol 140(3): 337-342.

YAMAMOTO T, UNUMA T AND AKIYAMA T. 2000. The influence of dietary protein and fat levels on tissue free amino acid levels of fingerling rainbow trout (Oncorhynchus mykiss). Aquaculture 180: 353-372. 